Thorax (1975), 30, 300.

\title{
A survey of asthma mortality in patients between ages 35 and 64 in the Greater London hospitals in 1971
}

\author{
G. M. COCHRANE and T.J. H. CLARK \\ Guy's and Brompton Hospitals
}

\begin{abstract}
Cochrane, G. M. and Clark, T. J. H. (1975). Thorax, 30, 300-305. A survey of asthma mortality in patients between ages 35 and 64 in the Greater London hospitals in 1971. We have examined the death certificates from all patients aged 35-64 years who were recorded as dying from asthma in Greater London Council hospitals in 1971. Of the 47 death certificates studied, nine suggested that the primary cause of death was not asthma. From the remaining 38 deaths we have obtained 36 case records and found that 15 deaths occurred outside hospital and another two patients died in hospital having been admitted in a stable state. We have examined the remaining 19 case records to find out the circumstances of death in patients with asthma who die in hospital.

We have been unable to exclude the possibility that many of the deaths in hospital were avoidable. Assessment of severity in most patients was incomplete, as judged by a retrospective analysis of case records, and many of the patients would be regarded as having had insufficient treatment. Four patients did not receive corticosteroids and in a further three the dose given was small. No physiological assessment of airflow obstruction was made in over half the patients.

A comparison with 19 survivors of an admission to hospital with asthma did not provide enough information to account for the deaths. The survivors were in hospital for a shorter period of time, were slightly less ill, and were given comparable treatment regimens. Both groups of patients were inadequately assessed, and sedatives were given to approximately $70 \%$ of all subjects studied.

The deaths in hospital usually occurred suddenly in the early morning in general medical wards.
\end{abstract}

There has been a number of studies concerning deaths from asthma in young people dying suddenly at home (Speizer, Doll, and Heaf, 1968; Inman and Adelstein, 1969; Fraser et al., 1971) but little information exists about the circumstances of death in patients over 35 years who die in hospital (Roe, 1965; van Metre, 1966). We have set out to look at the deaths from asthma in patients between ages 35-64 occurring in Greater London Council (GLC) hospitals during 1971. Our aim has been to see if the deaths were potentially avoidable or were genuinely sudden and unexpected.

1Taken from the Registrar General's Statistical Review of England and Wales for 1971. ICD 493 excludes death certificates which mention bronchitis or emphysema as well as asthma and therefore the deaths attributable to asthma may be greater

\section{METHODS}

There were 1,198 deaths attributed to asthma in England and Wales in $1971^{1}, 486$ male and 710 female; of these, $554(46 \%)$ were 35-64 years old and a further $441(37 \%)$ were 65 or over. One hundred and forty-nine of all asthma deaths occug red in GLC hospitals, $47(32 \%)$ aged 35-64 Patients dying of asthma aged 65 years and ovef were not studied in view of the uncertainty diagnosis.

Of the 47 deaths in the age group 35-64 years we excluded nine from further study as other cors ditions may have been the cause of death. With the consent of the consultants involved we ob tained the case records of 36 patients. Fifteen deaths were excluded from study as they occurred 
before admission to hospital, a further two patients were excluded as they were admitted only for an investigation of their asthma and not in an acute attack, and two case records were unobtainable.

We have compared the data of 19 patients aged 35-64 years dying from asthma during 1971 with the last 19 patients aged 35-64 years who survived an admission to a GLC hospital with acute asthma during 1972-73 (such a group is not strictly comparable but we were unable to obtain a truly random control group).

\section{RESULTS}

The case records of those 19 patients who died in hospital as a result of asthma were examined and their clinical details are given in Table I which also shows the clinical details of 19 patients who survived a hospital admission with an exacerbation of their asthma. In no patient was the grade of severity of asthmatic attack noted (Jones, 1971) but in all but one patient the history was adequate to surmise their probable grade of severity on admission (see Table II). In five out of eight patients who had a serum potassium estimated the value was below the lower limit of normal; in only one patient was the potassium level reestimated and this patient was the only one to be prescribed potassium supplements. Measurements of airway obstruction and arterial blood gas tensions were sparse (Table III). The significance of the arterial $\mathrm{O}_{2}$ tension is obscure as there were limited details of which patients were receiving oxygen and what inspired $\mathrm{O}_{2}$ concentration was given. The $\mathrm{PaCO}_{2}$ in one patient was recorded as $11.31 \mathrm{kPa}(85 \mathrm{mmHg}) 12$ hours after intravenous injection of diazepam $10 \mathrm{mg}$. None of the six

T A B L E I I

\section{METHOD FOR GRADING SEVERITY OF ASTHMA ${ }^{1}$}

\begin{tabular}{l|l}
\hline Grade I & $\begin{array}{l}\text { Able to carry out housework or job with difficulty (IA) } \\
\text { or great difficulty (IB) } \\
\text { Confined to a chair or bed but able to get up with } \\
\text { moderate difficulty (IIA) or with great difficulty (IIB) }\end{array}$ \\
Grade II & $\begin{array}{l}\text { Confined to a chair or bed } \\
\text { Moribund }\end{array}$ \\
\hline Grade IV
\end{tabular}

After Jones (1971).

T A B L E I I I

PHYSIOLOGICAL ASSESSMENT

\begin{tabular}{|c|c|c|c|c|}
\hline & \multicolumn{4}{|c|}{ Number of Patients } \\
\hline & $\underset{\text { Admission }}{\text { On }}$ & & $\begin{array}{c}\text { With } \\
\text { Hours }\end{array}$ & 24 \\
\hline \multirow[t]{2}{*}{$\begin{array}{l}\text { PEFR } \\
\text { FEV } \\
\text { FVC } \\
\text { Arterial blood gases }\end{array}$} & $\begin{array}{l}1 \\
4 \\
4\end{array}$ & & & \\
\hline & $\begin{array}{l}\mathrm{PaO}_{2} \\
(\mathrm{kPa})\end{array}$ & $\begin{array}{c}\mathrm{PaCO}_{2} \\
(\mathrm{kPa})\end{array}$ & pH & $\underset{(\mathrm{mmol} / \mathrm{l})}{\mathrm{HCO}_{3}}$ \\
\hline $\begin{array}{l}\text { On admission } \\
\text { During admission }\end{array}$ & $\begin{array}{l}9.84 \text { (air) } \\
7.05 \text { (air) } \\
7.71 \text { (?O. } \%) \\
9.04 \text { (air) } \\
6.78\left(? \mathrm{O}_{2} \%\right) \\
10.77\left(? \mathrm{O}_{2} \%\right)\end{array}$ & $\begin{array}{r}3 \cdot 19 \\
8 \cdot 65 \\
5 \cdot 99 \\
8 \cdot 65 \\
11 \cdot 31 \\
8 \cdot 11\end{array}$ & $\begin{array}{l}7 \cdot 53 \\
\overline{-} \\
7 \cdot 12 \\
7 \cdot 40\end{array}$ & $\begin{array}{l}19 \cdot 5 \\
\overline{-} \\
31 \\
32\end{array}$ \\
\hline
\end{tabular}

15 patients had no physiological assessment on admission.

10 patients had no assessment at any stage of their stay in hospital.

2 patients had both spirometry and arterial blood gas tensions measured on admission.

T A B L E I

BASIC CLINICAL DETAILS ON ADMISSION

\begin{tabular}{|c|c|c|c|c|c|c|c|}
\hline \multirow[b]{2}{*}{ Clinical Details } & & \multicolumn{3}{|c|}{ Group A } & \multicolumn{3}{|c|}{ Group B } \\
\hline & & Male & Female & Total & Male & Female & Total \\
\hline $\begin{array}{l}\text { Number } \\
\text { Age (yr) } \\
\text { History (yr) } \\
\text { Admission (days) }\end{array}$ & $\begin{array}{l}\text { Range } \\
\text { Mean } \\
\text { Range } \\
\text { Mean } \\
\text { Range } \\
\text { Mean }\end{array}$ & $\begin{array}{l}6 \\
37-61 \\
54 \cdot 3 \\
0 \cdot 25-28 \\
7 \cdot 2 \\
2-32 \\
14 \cdot 0\end{array}$ & $\begin{array}{l}13 \\
40-64 \\
55 \cdot 0 \\
1 \cdot 25-43 \\
14 \cdot 8 \\
1-23 \\
5 \cdot 3\end{array}$ & $\begin{array}{l}19 \\
37-64 \\
54 \cdot 8 \\
0 \cdot 25-43 \\
12 \cdot 4 \\
1-32 \\
8 \cdot 1\end{array}$ & $\begin{array}{l}8 \\
39-62 \\
49 \cdot 8 \\
0 \cdot 1-30 \\
14 \cdot 7 \\
2-12 \\
5 \cdot 9\end{array}$ & $\begin{array}{l}11 \\
37-64 \\
49 \cdot 8 \\
0 \cdot 5-24 \\
8 \cdot 0 \\
1-12 \\
4 \cdot 9\end{array}$ & $\begin{array}{l}19 \\
37-64 \\
49 \cdot 8 \\
0 \cdot 1-30 \\
11 \cdot 3 \\
1-12 \\
5 \cdot 3\end{array}$ \\
\hline $\begin{array}{l}\text { Clinical grade } \\
\text { I } \\
\text { II } \\
\text { III } \\
\text { IV } \\
\text { Insufficient information in notes } \\
\text { Pulse rate (beats/min) } \\
\text { Respiratory rate (breaths/min) } \\
\text { Potassium (mmol/1) }\end{array}$ & $\begin{array}{l}\text { Range } \\
\text { Mean } \\
\text { SD } \\
\text { Range } \\
\text { Mean } \\
\text { SD } \\
\text { Range } \\
\text { Mean } \\
\text { SD }\end{array}$ & $\begin{array}{l}1 \\
0 \\
4 \\
0 \\
1 \\
90-140 \\
113 \\
19\end{array}$ & $\begin{array}{l}3 \\
5 \\
4 \\
1 \\
0 \\
80-140 \\
112 \\
19\end{array}$ & $\begin{array}{l}4 \\
5 \\
8 \\
1 \\
1 \\
80-140 \\
113 \\
19 \\
22-48^{2} \\
33 \\
12 \\
3 \cdot 0-5 \cdot 8^{3} \\
4 \cdot 05 \\
1 \cdot 09\end{array}$ & $\begin{array}{l}0 \\
6 \\
2 \\
0 \\
0 \\
78-200 \\
114 \\
38 \\
20-36 \\
26 \\
7 \cdot 2\end{array}$ & $\begin{array}{l}1 \\
7 \\
2 \\
0 \\
1 \\
84-124 \\
107 \\
14 \\
20-30 \\
26 \\
3 \cdot 7\end{array}$ & $\begin{array}{l}1 \\
13 \\
4 \\
0 \\
1 \\
78-200 \\
110 \\
26 \\
20-36 \\
26 \\
5 \cdot 1 \\
3 \cdot 3-4 \cdot 9 \cdot \\
4 \cdot 01 \\
0 \cdot 6\end{array}$ \\
\hline
\end{tabular}

1Group A: Asthmatic patients dying during admission.

IGroup B: Asthmatic patients discharged fit following admission.

Only recorded in 7 patients.

Only recorded in 7 patients.

'Only estimated in 14 patients. 
patients had repeat blood gas estimation or was treated with mechanical ventilation.

Chest radiographs were taken in all but two patients and neither pneumothorax nor pneumomediastinum was reported; we did not review the films. An electrocardiogram was taken in four patients, and in three there was evidence of right ventricular hypertrophy (dominant $R$ in V1 with right axis deviation). In nine patients a postmortem examination was carried out and in eight we obtained a copy of the report; no histology was available and the only consistent finding was widespread plugging of peripheral airways with mucus.

The length of terminal admission varied considerably (Table IV). An interesting feature was the time of day when death occurred; $13(68 \%)$ died between midnight and 08.00 hours, the remainder dying at even intervals throughout the rest of the day.

Only one patient was admitted to an intensive care unit and that was only for a period of two days. This patient died six days later in a general ward.

T A B L E I V

\begin{tabular}{c|c}
\hline $\begin{array}{c}\text { Duration of terminal admission (days) } \\
\text { Range } 1-32 \\
\text { Mean } 8 \cdot 1\end{array}$ & No. \\
\hline Interval between admission and death & \\
$0-48$ hours & \\
$2-3$ days & 7 \\
$4-7$ days & 4 \\
$8-14$ days & 2 \\
14 days & 3 \\
\hline Time of death (hours) & 3 \\
$00 \cdot 01-08 \cdot 00$ & \\
$08 \cdot 01-16.00$ & 13 \\
$16 \cdot 01-24 \cdot 00$ & 3 \\
\hline
\end{tabular}

The treatment regimens for the patients on admission and 24 hours preceding death are sume marized in Tables V and VI. Seven patients wer: receiving oral corticosteroids before admission and of these, three were taking over $7.5 \mathrm{mg}$ prednisolone per day. Three patients were res ceiving ACTH and one Synacthen depot. ThS range of oral bronchodilator therapy was large. (seven different preparations in nine patients $\vec{\omega}$ There appeared to be little relation between the severity of the attack (as surmised by us) and the treatment when admitted to hospital (see Tabie $\mathrm{V}$-patient 12 compared with patient 5). In ones patient (patient 7 , Tables $\mathrm{V}$ and VI) it was cor sidered by the medical and nursing staff that she was using her inhaler excessively despite being told of its dangers; this patient was not treated at any time with corticosteroids or ACTH and no assessment was made of airflow obstruction op blood gas tensions.

Fifteen of the 19 patients received sedation Ten patients received oral preparations and ig five sedation was given parenterally; in 11 seds tion was given within 12 hours of death, and in four patients deterioration of their clinical corn dition followed this treatment. Eight patients wers given diazepam, three promethazine, two nitra? zepam and one barbiturates; another was give benzoctamine. In two of the four cases where sedation appeared to cause respiratory depressiog diazepam was the preparation prescribed.

COMPARISON WITH SURVIVORS The 19 surviving patients were slightly younger in age and the cling cal grade of the severity of their asthmatic attack was slightly lower (see Table I and Figure). There

T A B L E V

TREATMENT ON ADMISSION AND DURING FIRST 24 HOURS

\begin{tabular}{|c|c|c|c|c|c|c|c|}
\hline Patient & Sex & Grade & $\begin{array}{l}\text { Hydrocortisone } \\
\text { (mg) }\end{array}$ & $\underset{\text { (mg) }}{\text { Aminophylline }}$ & $\begin{array}{c}\text { Prednisone } \\
\text { (mg) }\end{array}$ & $\underset{\text { (iu) }}{\text { ACTH }}$ & Bronchodilator \\
\hline $\begin{array}{r}1 \\
2 \\
3 \\
4 \\
5 \\
6 \\
7 \\
8 \\
9 \\
10 \\
11 \\
12 \\
13 \\
14 \\
15 \\
16 \\
17 \\
18 \\
19\end{array}$ & $\begin{array}{l}\mathbf{M} \\
\mathbf{F} \\
\mathbf{M} \\
\mathbf{F} \\
\mathbf{F} \\
\mathbf{F} \\
\mathbf{F} \\
\mathbf{F} \\
\mathbf{F} \\
\mathbf{F} \\
\mathbf{F} \\
\mathbf{M} \\
\mathbf{F} \\
\mathbf{M} \\
\mathbf{M} \\
\mathbf{F} \\
\mathbf{M} \\
\mathbf{F} \\
\mathbf{F}\end{array}$ & $\begin{array}{l}\text { ? } \\
\text { I } \\
\text { IB } \\
\text { IB } \\
\text { IIA } \\
\text { IIA } \\
\text { IIA } \\
\text { II } \\
\text { II } \\
\text { III } \\
\text { III } \\
\text { III } \\
\text { III } \\
\text { III } \\
\text { III } \\
\text { III } \\
\text { III } \\
\text { III }\end{array}$ & $\begin{array}{l}100 \text { IV stat } \\
- \\
\overline{-} \\
100 \text { IV stat } \\
100 \text { IM stat } \\
\overline{-} \\
\overline{800} \text { IV } \\
400 \text { IV } \\
- \\
\overline{800} \text { IV } \\
100 \text { IV stat } \\
100 \text { IV stat } \\
100 \text { IV stat } \\
300 \text { IV stat } \\
1000 \text { IV } \\
500 \text { IV }\end{array}$ & $\begin{array}{l}250 \text { IV stat } \\
- \\
- \\
\overline{250} \text { IV stat } \\
250 \text { IV stat } \\
\overline{250} \text { IV stat } \\
\overline{250} \text { IV stat } \\
250 \text { IV stat } \\
250 \text { IV stat } \\
500 \text { IV } \\
250 \text { IV stat } \\
600 \text { IV } \\
250 \text { IV stat } \\
\overline{37} \text { IV }\end{array}$ & $\begin{array}{l}\overline{-} \\
\overline{5} \\
7 \cdot 5 \\
\frac{60}{\overline{2}} \\
\overline{20} \\
\overline{60} \\
\overline{-} \\
\overline{20} \\
30 \\
40 \\
\overline{45} \\
-\end{array}$ & $\begin{array}{l}40 \\
\overline{-} \\
20 \\
= \\
= \\
= \\
= \\
= \\
= \\
=\end{array}$ & $\begin{array}{l}\text { - } \\
\text { Oral } \\
\text { Oral }+ \text { inhaler } \\
\text { Inhaler } \\
\text { Oral } \\
\text { Oral + inhaler } \\
\text { Oral } \\
- \\
\overline{-} \\
\text { Oral } \\
\overline{\text { Oral }} \\
\text { - } \\
\text { Oral } \\
\text { Oral }\end{array}$ \\
\hline
\end{tabular}

Stat means single dose; IV means total dose infused over 24 hours. 
T A B L E V I

TREATMENT AT TIME OF DEATH

\begin{tabular}{|c|c|c|c|c|}
\hline Patient & $\underset{\text { (mg) }}{\text { Prednisone/Day }}$ & $\underset{\text { (iu) }}{\mathrm{ACTH} / \mathrm{Day}}$ & Bronchodilator & $\begin{array}{c}\text { Hydrocortisone } \\
\text { (mg) }\end{array}$ \\
\hline $\begin{array}{r}1 \\
2 \\
3 \\
4 \\
5 \\
6 \\
7 \\
8 \\
9 \\
10 \\
11 \\
12 \\
13 \\
14 \\
15 \\
16 \\
17 \\
18 \\
19\end{array}$ & $\begin{array}{l}\bar{Z} \\
5 \\
7 \cdot 5 \\
20 \\
\overline{\bar{T}} \\
\frac{20}{\text { No record }} \\
\overline{\bar{T}} \\
\frac{40}{30} \\
40 \\
\frac{45}{-}\end{array}$ & $\begin{array}{l}\bar{z} \\
\overline{40} \\
\bar{z} \\
\bar{z} \\
\overline{70} \\
\bar{z} \\
\bar{z} \\
100\end{array}$ & $\begin{array}{l}\text { Oral } \\
\text { Oral } \\
\text { Oral + inhaler } \\
\overline{\text { Oral }}+\text { inhaler } \\
\text { Oral + inhaler } \\
\text { Oral + inhaler } \\
\overline{ } \\
\overline{\bar{O}} \\
\text { Oral + inhaler } \\
\text { Oral } \\
\text { Oral } \\
\overline{-} \\
\overline{-}\end{array}$ & $\begin{array}{l}= \\
= \\
= \\
= \\
= \\
= \\
\bar{z} \\
\frac{100}{200} \mathrm{IV} \\
\frac{100}{-} \mathrm{IV}\end{array}$ \\
\hline
\end{tabular}

Stat means single dose; IV means total dose infused over 24 hours.

A. Asthmatic patients dying during admission

B. Asthmatic patients discharged fit following admission

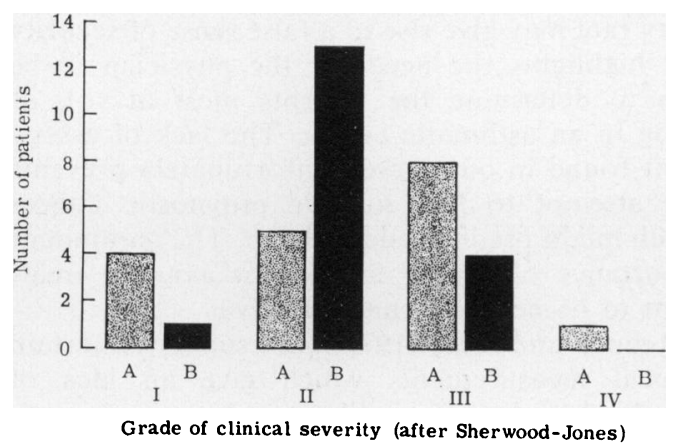

FIGURE Histogram of the number of patients admitted with each grade of clinical severity in the two groups of patients. were no significant differences between the groups in terms of blood eosinophilia and the frequency of positive skin tests to common allergens. The assessment of airflow obstruction on admission in the survivors was confined to the PEFR being measured in five patients, and arterial blood gas tensions were measured in only two patients.

The treatment prescribed for the survivors on admission is shown in Table VII and although our impression is that they were clinically less severe as a group but received more active treatment we were unable to show a significant difference between survivors and those who died as a result of asthma. We attempted to see if there was a significant difference between the pulse rate on discharge and the last recorded pulse rate in the 24 hours preceding death, but adequate data were unavailable. The amount and type of sedation

T A B L E V I I

TREATMENT ON ADMISSION AND DURING FIRST 24 HOURS (SURVIVORS)

\begin{tabular}{|c|c|c|c|c|c|c|}
\hline Patient & Sex & Grade & $\begin{array}{l}\text { Hydrocortisone } \\
(\mathrm{mg})\end{array}$ & $\underset{\text { (mg) }}{\text { Aminophylline }}$ & $\begin{array}{l}\text { Prednisone } \\
\text { (mg) }\end{array}$ & Bronchodilator \\
\hline $\begin{array}{r}1 \\
2 \\
3 \\
4 \\
5 \\
6 \\
7 \\
8 \\
9 \\
10 \\
11 \\
12 \\
13 \\
14 \\
15 \\
16 \\
17 \\
18 \\
19\end{array}$ & $\begin{array}{l}\mathbf{F} \\
\mathbf{F} \\
\mathbf{M} \\
\mathbf{F} \\
\mathbf{M} \\
\mathbf{M} \\
\mathbf{F} \\
\mathbf{F} \\
\mathbf{F} \\
\mathbf{M} \\
\mathbf{F} \\
\mathbf{M} \\
\mathbf{F} \\
\mathbf{F} \\
\mathbf{M} \\
\mathbf{F} \\
\mathbf{M} \\
\mathbf{M} \\
\mathbf{F}\end{array}$ & $\begin{array}{l}\text { ? } \\
\text { I } \\
\text { II } \\
\text { II } \\
\text { II } \\
\text { II } \\
\text { II } \\
\text { II } \\
\text { II } \\
\text { II } \\
\text { II } \\
\text { II } \\
\text { II } \\
\text { II } \\
\text { III } \\
\text { III } \\
\text { III } \\
\text { III }\end{array}$ & $\begin{array}{l}200 \text { IV } \\
= \\
\overline{300} \text { IV } \\
300 \text { IV } \\
= \\
\bar{z} \\
200 \text { IV } \\
100 \text { IV stat } \\
800 \text { IV } \\
\overline{100} \text { IV stat } \\
200 \text { IV } \\
400 \text { IV } \\
200 \text { IV } \\
=\end{array}$ & $\begin{array}{l}1050 \text { IV } \\
250 \text { IV stat } \\
\overline{-} \\
500 \text { IV } \\
1000 \text { IV } \\
250 \text { IV stat } \\
\overline{250 ~ I V ~ s t a t ~} \\
500 \text { IV } \\
500 \text { IV } \\
\overline{250} \text { IV stat } \\
250 \text { IV stat } \\
500 \text { IV } \\
250 \text { IV stat } \\
250 \text { IV stat } \\
250 \text { IV stat }\end{array}$ & $\begin{array}{l}= \\
= \\
= \\
\overline{3} \\
40 \\
40 \\
40 \\
40 \\
40 \\
60 \\
60 \\
\frac{15}{20} \\
40\end{array}$ & $\begin{array}{l}\text { Oral + inhaler } \\
\text { Oral } \\
\text { Oral }+ \text { inhaler } \\
\text { Oral } \\
\text { Oral } \\
\text { Inhaler } \\
\text { Oral } \\
\text { Oral + inhaler } \\
\text { Oral } \\
\text { Inhaler } \\
\overline{\text { Oral }}+\text { inhaler } \\
\text { Oral } \\
\overline{-} \\
\overline{\text { Oral }} \\
\overline{\text { Oral }}\end{array}$ \\
\hline
\end{tabular}


given to survivors did not differ from that given to patients who died.

There are many suggested protocols for a full assessment of acute asthma but that proposed by Stark (1972) is probably the most complete; we have modified and simplified his assessment protocol (Table VIII) and found that only two patients who died had an assessment as complete as the modified protocol. However both of these patients were sedated. Similar failures of assessment were also found in the 19 survivors.

\begin{tabular}{l|l}
\multicolumn{2}{c}{ T A B L E V I I I } \\
\multicolumn{1}{|c|}{ ADEQUATE ASSESSMENT OF SEVERE ASTHMA } \\
(STARK, 1972)
\end{tabular}

\section{DISCUSSION}

Although most of the deaths were considered to be sudden and unexpected we were unable to exclude the possibility that this was caused by a failure of assessment of the severity of the attack with consequent failure to treat the patient effectively. The failure of assessment may in part have been caused by a lack of alertness to the possibility of sudden death as the case fatality rate is low and most patients recover from an attack of severe asthma. It is also possible that, as in any retrospective study, the data available in the notes are less than that available to the physician managing the case and the assessment had been carried out completely but no note made of it, or the information had been lost in the intervening years.

A significant fall in asthma mortality was reported by Jones (1971) associated with the use of a specialized unit where all patients with asthma whose severity was greater than grade I were admitted under nurses and doctors trained in the treatment of severe asthma. This observation suggests that failure of assessment may lead to failure of effective treatment and also suggests that asthmatic patients should as far as possible be cared for by physicians with special interest and experience in the disease.

There were approximately 2000 admissions with asthma to GLC hospitals in 1971 in the age range 35-64 years (extrapolated from unpublished data from HIPE 1971 supplied by Dr. A. M. Adel- stein); of these admissions 47 patients were re $\mathrm{ren}^{\stackrel{\overrightarrow{7}}{+}}$ corded as dying of asthma, giving a crude hospita? admission mortality of $2 \cdot 4 \%$. However our studi suggests only 19 of the 47 patients died of acute asthma in hospital, giving a hospital admissior mortality of approximately $1 \%$.

Our survey has also drawn attention to the fact that a substantial number of "hospital deaths" from asthma take place before arrival at hospitado and this had to be taken into account when we tried to estimate the mortality rate for hospitak admissions with asthma. Further extrapolation from our data suggests that in the age group 55-64 years there is one death in every 65 admis sions. Previous studies have shown the hospitaP mortality to be between $1.3 \%$ (Rebuck and Reid? 1971) and $12 \%$ (Rees, Millar, and Donald, 1968) but include patients with a wider age range thare in our study, and the populations studied wer comparatively small (76 and 25 admissions re $\vec{\imath}$ spectively). The comparatively low hospital mor vr tality rate may give rise to a false sense of security and highlights the need for the physician to be able to determine the patients most at risk of dying in an asthmatic attack. The lack of assess ment found in our survey unfortunately prevente any attempt to find suitable prognostic indices which might predict sudden death. The paramoun $\overrightarrow{\bar{p}}$ importance of proper assessment assumes treat ment to be necessary and effective.

Rebuck and Read (1971) have suggested certain. clinical measurements which give an idea of severity but their data, like ours, are inadequate to set up a scoring system of severity giving weight to those symptoms and clinical measure 3 ments which presage death. We need more infor mation gained from prospective studies before accurate prognosis is attainable and the methods of assessment will need to be evaluated to see which are important and to find out the relation between assessment and treatment needs. We would like to make the following recommenda fr tions in the hope that death from acute asthma becomes a rarity and that when such a death occurs the information acquired provides a bettef insight into the cause of death than that currently available.

\section{RECOMMENDATIONS}

1. The threshold for anxiety regarding a patien with acute asthma should be lowered as we appeaf at present to be too complacent in our assessmene of treatment needs and appear to underestimate the likelihood of death., The category grade I of 
its equivalent in other classifications should be taken to indicate severe asthma requiring a full assessment of the attack and prompt effective treatment.

Patients should be advised to seek medical attention earlier whenever there is an increase in symptoms not responding to their usual treatment.

2. Measurements of functional abnormality such as peak expiratory flow rate should become a routine part of assessment which should also include an assessment of the circulation and an estimate of arterial blood gas tensions.

3. It is important to acquire detailed information about the circumstances of any deaths attributed to asthma in order to evaluate whether earlier admission, more intensive treatment or care by special units is likely to be a practical way of reducing mortality. In view of this and the mortality caused by asthma there are compelling grounds for setting up a similar machinery to that involved with the reports on confidential enquiries into maternal deaths in England and Wales. These reports have added considerably to the knowledge of obstetricians and such self-critical appraisal is apparently needed in the management of asthma (Editorial, 1972).

We should like to thank Dr. A. M. Adelstein and his staff for supplying us with death certificates and for all their help in the preparation of this report. We are most grateful to have been given permission to examine the case records and should like to thank all the consultants concerned for their help.

We are particularly indebted to Miss Karen Henley for secretarial help without which this report could not have been prepared.
G. M. Cochrane was supported by a grant from Sir Philip Oppenheimer's Friends of Guy's Fund.

\section{REFERENCES}

Editorial (1972). Nativity, chance or death. British. Journal of Hospital Medicine, 8, 363.

Fraser, P. M., Speizer, F. E., Waters, S. D. M., Doll, R., and Mann, N. M. (1971). The circumstances preceding death from asthma in young people in 1968 to 1969. British Journal of Diseases of the Chest, 65, 71.

Inman, W. H. W. and Adelstein, A. M. (1969). Rise and fall of asthma mortality in England and Wales in relation to use of pressurised aerosols. Lancet, 2, 279.

Jones, E. S. (1971). The intensive therapy of asthma. Proceedings of the Royal Society of Medicine, 64, 1151.

Rebuck, A. S. and Read, J. (1971). Assessment and management of severe asthma. American Journal of Medicine, 51, 788.

Rees, H. A., Millar, J. S., and Donald, K. W. (1968). A study of the clinical course and arterial blood gas tensions of patients in status asthmaticus. Quarterly Journal of Medicine, 37, 541 .

Roe, P. F. (1965). Sudden death in asthma. British Journal of Diseases of the Chest, 59, 158.

Speizer F. E., Doll, R., and Heaf, P. (1968). Observations on recent increase in mortality from asthma. British Medical Journal, 1, 335.

Stark, J. E. (1972). Status asthmaticus. British Journal of Hospital Medicine, 8, 241.

van Metre, T. E. Jr (1966). Death in asthmatics. Transactions of the American Clinical and Climatological Association, 78, 58.

Requests for reprints to: Dr. T. J. H. Clark, Guy's Hospital, London SE1 9RT. 